\title{
Comparison of motivations and concerns for genetic testing in hereditary colorectal and breast cancer syndromes
}

\author{
J Balmaña, E M Stoffel, K M Emmons, J E Garber, S Syngal
}

J Med Genet 2004;41:e44 (http://www.jmedgenet.com/cgi/content/full/41/4/e44). doi: 10.1136/jmg.2003.012526

G enetic testing for predisposition cancer syndromes has been broadly implemented in the clinical setting in the last several years. Some of the most recognisable familial cancer syndromes for which genetic testing is available are hereditary non-polyposis colorectal cancer (HNPCC), familial adenomatous polyposis (FAP), and hereditary breast and ovarian syndrome (HBOS). Genetic testing in these individuals may have relevant medical and psychological implications for them and their families. Whether individuals at risk for hereditary colorectal syndromes such HNPCC or FAP have different motivations and concerns about genetic testing than individuals with HBOS is not known.

The first studies addressing motivations for genetic testing for cancer predisposition were carried out in the mid 1990s. ${ }^{1-6}$ These studies were conducted not in people actually undergoing testing but in the general population or among firstdegree relatives of individuals with breast, ovarian, or colon cancer. They revealed that willingness to undergo genetic testing was associated with higher perception of cancer risk or of being a gene carrier and that the most common reasons for their stated intent to pursue genetic testing were to learn about one's children's risks, be reassured regarding one's own risk, and a wish to increase screening practices. Concerns about genetic testing included mistrust of test accuracy, worry about losing health insurance, and fear of emotional reactions if the test was positive.

Despite the high uptake for genetic testing predicted by the above studies, rates of testing were lower than expected when it actually became available for families with HBOS or HNPCC syndromes. ${ }^{78}$ Reported barriers to genetic testing among individuals at risk for HBOS were concerns about losing health insurance, and the belief that test results might not be accurate. ${ }^{7}$ A low level of education and the presence of depression symptoms, especially among women, were found to be predictors of low uptake of genetic test results among individuals at risk for HNPCC. ${ }^{8}$

In contrast to the initial studies that were not conducted in high risk populations, there have been more recent studies reporting motivations and concerns for genetic testing among individuals fulfilling clinical criteria for hereditary syndromes, such as HBOS ${ }^{10}$ and HNPCC. ${ }^{11}{ }^{12}$ In these studies, the main reasons to undergo genetic testing were to assess children's risk, to make decisions about screening and preventive surgeries, and to reduce uncertainty about being a carrier. Main concerns seemed to be fear of discrimination ${ }^{12}$ and expected adverse emotional reactions. ${ }^{13}$ Two of these studies compared motivations between affected and unaffected subjects, ${ }^{10}$ or between male and female individuals. ${ }^{9}$

However, there are no previous reports comparing motivations and concerns about genetic testing among different hereditary cancer syndromes. Our hypothesis was that reasons for undergoing genetic testing may differ among different hereditary cancer syndromes. Knowledge of these motivations may help genetic counsellors and physicians

\section{Key points}

- Authors have created a new tool for assessing the motivations and concerns about genetic testing for hereditary cancer syndromes (MACGNET instrument). The instrument is currently in the validation process of its revised version.

- According to this study individuals at risk for hereditary non-polyposis colorectal cancer and familial adenomatous polyposis are more likely to undergo genetic testing for medical decision-making than those at risk for hereditary breast and ovarian syndrome $(\mathrm{P}<0.05)$.

- Individuals in this cohort, which included only individuals who had elected to undergo genetic testing, expressed little concern regarding their perceived ability to cope with the genetic results.

- Independently of the hereditary cancer syndrome, men undergoing genetic testing were more influenced by their partner's opinion regarding testing than were women $(P=0.05)$. Unaffected individuals were more likely to undergo genetic testing for cancer prevention and medical management compared to affected subjects $(P=0.03)$, although they expressed more fear of discrimination $(P=0.03)$.

tailor pre-test genetic sessions and understand the impact of genetic testing on different hereditary cancer syndrome populations.

We conducted a cross-sectional survey of individuals who had decided to undergo genetic testing for different hereditary cancer syndromes. Our goals were: (1) to explore potential differences in motivations and concerns about genetic testing among individuals at risk for HNPCC, FAP, and HBOS syndromes; and (2) to evaluate the influence of several clinical and demographic factors on the decisionmaking for undergoing genetic testing.

\section{METHODS}

\section{Study population and study procedures}

A total of 130 individuals at risk for or affected by HNPCC $(n=37)$, FAP $(n=26)$, and HBOS $(n=67)$ who were eligible for clinical genetic testing were enrolled in the study. They were evaluated at the Cancer Risk and Prevention Clinic at Dana-Farber Cancer Institute in Boston between March 1997 and August 2002. All potential participants were invited by

Abbreviations: FAP, familial adenomatous polyposis; $\mathrm{HBOS}$, hereditary breast and ovarian syndrome; HNPCC, hereditary nonpolyposis colorectal cancer 
Table 1 Description of subscales

\begin{tabular}{lllrr}
\hline Subscale & $\begin{array}{l}\text { Number of } \\
\text { items }\end{array}$ & $\begin{array}{l}\text { Range of possible } \\
\text { scores* }\end{array}$ & $\begin{array}{l}\text { Range of observed } \\
\text { scorest }\end{array}$ & Mean (SD)t \\
\hline Prevention and medical care (PMC) & 11 & $11-55$ & $14-55$ & $44.44(7.36)$ \\
Future planning (FP) & 3 & $3-15$ & $3-15$ & $9.73(2.61)$ \\
Partner's influence (P) & 4 & $4-20$ & $11-20$ & $16.08(2.40)$ \\
Ability to cope (ATC) & 6 & $6-30$ & $6-22$ & $12.34(4.07)$ \\
Fear of discrimination (FOD) & 6 & $6-30$ & $3-26$ & $14.62(4.38)$ \\
\hline \multirow{2}{*}{ *Each item was scored from 1, strongly disagree, to 5, strongly agree; tall study individuals. } \\
\hline
\end{tabular}

telephone or personal interview to participate in a research study on genetic testing for cancer susceptibility. The purpose of the study was to describe the impact of participation in a clinical predisposition testing program on health behaviours, genetic knowledge, perceptions of cancer risk, and decisions about genetic testing for management of cancer risk. Individuals who were recommended to undergo genetic testing (by their physician or in a risk-assessment visit by a genetic counsellor) were invited to participate in the study and completed the baseline questionnaires prior to the genetic counselling visit and the genetic testing. Questionnaires were mailed to participants. The individual's status was classified as affected if they had a history of breast, colon cancer, or phenotypic manifestations of their syndrome, and unaffected if they did not have any of these features. This study was approved by the Office for Protection of Research Subjects of the Dana-Farber Cancer Institute.

\section{Instruments}

Data were collected about sociodemographic and medical history, genetic knowledge, attitudes and motivations toward testing, and health habits using self-administered questionnaires. Participants also completed two psychological measures, the Brief Symptom Inventory (BSI) and the Center for Epidemiologic Studies-Depression scale (CES-D). Demographic variables included age, gender, ethnicity, religion, education level, household income, relationship status, having children, and disease status (affected with cancer or phenotypic manifestations of the hereditary syndrome versus unaffected). Risk perception of developing cancer was measured using a 5-point Likert-type scale ("very high", "high", "average", "low", "very low").

At the time this study was initiated, there were few instruments that assessed motivations and concerns for genetic testing in hereditary cancer syndromes, so a new instrument was developed for the purpose of the study. Items were created based on clinical experience of the researchers and selection of some specific domains was based on previous research done by other authors. ${ }^{35}$ The motivation questionnaire consisted of 37 items scored in a 5-point Likert-type scale, ranging from "strongly agree" to "strongly disagree". The questionnaire was subsequently organised into six

Table 2 Demographics

\begin{tabular}{|c|c|c|c|c|}
\hline Characteristics & HNPCC $(n=37)$ & FAP $(n=26)$ & HBOS $(n=67)$ & P value* \\
\hline \multicolumn{5}{|l|}{ Gender } \\
\hline Male & $11(30 \%)$ & $7(27 \%)$ & $6(9 \%)$ & \\
\hline Female & $26(70 \%)$ & $19(73 \%)$ & $61(91 \%)$ & 0.02 \\
\hline Age, mean (SD) & $43.3(12.9)$ & 38.1 (12.3) & $47.3(12.6)$ & 0.01 \\
\hline \multicolumn{5}{|l|}{ Race } \\
\hline Caucasian & $94 \%$ & $92 \%$ & $100 \%$ & \\
\hline African-American & $0 \%$ & $0 \%$ & $0 \%$ & \\
\hline Latin & $6 \%$ & $0 \%$ & $0 \%$ & \\
\hline Asian-American & $0 \%$ & $4 \%$ & $0 \%$ & NS \\
\hline \multicolumn{5}{|l|}{ Religion } \\
\hline Protestant & $28 \%$ & $15 \%$ & $14 \%$ & NS \\
\hline Catholic & $42 \%$ & $65 \%$ & $24 \%$ & 0.01 \\
\hline Jewish & $6 \%$ & $4 \%$ & $58 \%$ & 0.001 \\
\hline No religion & $17 \%$ & $11 \%$ & $2 \%$ & NS \\
\hline \multicolumn{5}{|l|}{ Education } \\
\hline$<$ College & $49 \%$ & $61 \%$ & $17 \%$ & \\
\hline$>$ College & $51 \%$ & $39 \%$ & $83 \%$ & 0.001 \\
\hline \multicolumn{5}{|l|}{ Household income } \\
\hline$<\$ 75000$ & $42.5 \%$ & $72 \%$ & $31 \%$ & \\
\hline$>\$ 75000$ & $57.5 \%$ & $28 \%$ & $69 \%$ & 0.002 \\
\hline \multicolumn{5}{|l|}{ Relationship status } \\
\hline Single, divorced or widowed & $30 \%$ & $35 \%$ & $27 \%$ & \\
\hline Married or cohabiting & $70 \%$ & $65 \%$ & $73 \%$ & NS \\
\hline \multicolumn{5}{|l|}{ Individuals with children } \\
\hline Yes & $76 \%$ & $65 \%$ & $80 \%$ & \\
\hline No & $24 \%$ & $35 \%$ & $20 \%$ & NS \\
\hline \multicolumn{5}{|l|}{ Disease status } \\
\hline Affected & $51 \%$ & $73 \%$ & $43 \%$ & \\
\hline Unaffected & $49 \%$ & $27 \%$ & $57 \%$ & 0.04 \\
\hline \multicolumn{5}{|l|}{ Risk perception of cancer } \\
\hline High, very high & $78 \%$ & $61 \%$ & $73 \%$ & \\
\hline Average, low, very low & $22 \%$ & $39 \%$ & $27 \%$ & NS \\
\hline \multicolumn{5}{|l|}{ Perception of test results } \\
\hline I have an altered cancer gene & $74 \%$ & $83 \%$ & $74 \%$ & \\
\hline I don't have an altered cancer gene & $26 \%$ & $17 \%$ & $26 \%$ & NS \\
\hline
\end{tabular}


subscales based on a factor analysis and was reduced to 30 items. Cronbach's $\alpha$ was 0.77 for the entire questionnaire. Items from two subscales appeared to be measuring a similar construct and were combined based on rational and logical analysis. The final instrument consisted of five subscales. Three subscales addressed motivations for undergoing genetic testing, which included gaining knowledge for cancer prevention and obtaining information to guide medical management, planning for the future, and evaluation of a partner's influence on undergoing genetic testing. Two subscales addressed concerns about genetic testing, including ability to cope with test results and fear of discrimination. Each item was scored from 1, "strongly disagree", to 5, "strongly agree", based on the individual's response. The responses to each item were summed for each individual to create a score for each subscale. The maximum score of a subscale depended on the number of items that constituted that particular subscale. The instrument was named "the Motivations And Concerns for GeNEtic Testing (MACGNET) questionnaire". Table 1 summarises all subscales and their score ranges. Items of the MACGNET instrument are given in Appendix A.

\section{Statistical analysis}

Descriptive statistics (that is, frequencies and means) were generated to characterise the population in terms of sociodemographics, perception of cancer risk, and expectations of test result. Some continuous and ordinal variables such as age, education, and household income were dichotomised so that all predictor variables would have the same number of categories in order to give equal weight to all predictors and to facilitate the interpretation of the multivariable linear regression analysis.

Contingency-table analysis for categorical variables (that is $\chi^{2}$ and Fisher's exact test) were performed to compare differences in demographics among the three hereditary cancer syndromes. The mean scores of each subscale between the breast and colon group were compared using $t$ test. ANOVA with post-hoc comparisons (Tukey's test) was performed to compare mean scores of each subscale among hereditary cancer syndromes (HNPCC, FAP, and HBOS). Multiple linear regression modelling was performed for each subscale of motivations and concerns regarding genetic testing. Any variable with an association in the univariate analysis that was significant at $\mathrm{P}<0.25$ was included in the multivariable model; P values were two-sided. All statistical analyses were performed with SPSS version 11.5 (Chicago, IL).

\section{RESULTS}

\section{Demographics}

Table 2 outlines the demographics of the study population. Subjects were predominantly female $(70,73$ and $91 \%$ in

Table 3a Univariate and multivariable analysis of motivations for undergoing genetic testing among HNPCC, FAP, and HBOS syndromes: prevention and medical care subscale

\begin{tabular}{|c|c|c|c|}
\hline Prevention and medical care subscale & $n$ & PMC score, mean (SD) & $P$ value \\
\hline \multicolumn{4}{|l|}{ Cohort } \\
\hline HNPCC & 37 & $45.54(5.71)$ & \\
\hline FAP & 26 & $47.80(6.20)$ & \\
\hline HBOS & 67 & $42.53(8.04)$ & $0.004^{*}$ \\
\hline \multicolumn{4}{|l|}{ Age } \\
\hline$<40$ years & 52 & $46.01(6.47)$ & \\
\hline$>40$ years & 76 & $43.59(7.65)$ & 0.06 \\
\hline \multicolumn{4}{|l|}{ Gender } \\
\hline Female & 105 & $44.14(7.40)$ & \\
\hline Male & 24 & $46.45(6.28)$ & 0.15 \\
\hline \multicolumn{4}{|l|}{ Disease status } \\
\hline Affected & 67 & $43.35(7.33)$ & \\
\hline Unaffected & 63 & $45.60(7.27)$ & 0.08 \\
\hline \multicolumn{4}{|l|}{ Education } \\
\hline$>$ College & 84 & $45.37(6.43)$ & \\
\hline$<$ College & 45 & $44.14(7.64)$ & 0.35 \\
\hline \multicolumn{4}{|l|}{$\begin{array}{l}\text { Income } \\
\text { Incoge }\end{array}$} \\
\hline$<\$ 75000$ & 52 & $44.80(6.75)$ & \\
\hline$>\$ 75000$ & 70 & $44.41(7.76)$ & 0.77 \\
\hline \multicolumn{4}{|l|}{ Partner } \\
\hline No & 38 & $45.02(6.71)$ & \\
\hline Yes & 91 & $44.38(7.48)$ & 0.64 \\
\hline \multicolumn{4}{|l|}{ Individuals with children } \\
\hline No & 31 & $46.35(5.05)$ & \\
\hline Yes & 98 & $44.01(7.74)$ & 0.11 \\
\hline \multicolumn{4}{|l|}{ Risk perception of cancer } \\
\hline High, very high & 89 & $45.17(6.70)$ & \\
\hline Average, low, very low & 35 & $44.76(6.91)$ & 0.76 \\
\hline \multicolumn{4}{|l|}{ Perception of test results } \\
\hline Have an altered gene & 84 & $44.07(7.67)$ & \\
\hline Do not have an altered gene & 27 & $46.00(7.03)$ & 0.25 \\
\hline \multicolumn{2}{|l|}{ Multiple linear regression analysis } & Regression coefficient & $P$ value \\
\hline \multicolumn{2}{|l|}{ Intercept } & 40.84 & \\
\hline \multicolumn{2}{|l|}{ HNPCC† } & 2.89 & 0.05 \\
\hline \multicolumn{2}{|l|}{ FAPt } & 5.47 & 0.002 \\
\hline \multicolumn{2}{|l|}{ Disease status (unaffected) } & 2.84 & 0.03 \\
\hline \multicolumn{2}{|l|}{ Gender (female) } & -0.66 & 0.69 \\
\hline \multicolumn{2}{|l|}{ Age ( $>40$ years) } & -0.79 & 0.58 \\
\hline \multicolumn{2}{|l|}{ Individuals with children } & -0.87 & 0.58 \\
\hline
\end{tabular}


HNPCC, FAP, and HBOS syndromes, respectively $(\mathrm{P}=0.02))$. Mean age of participants was significantly younger among the FAP cohort $(\mathrm{P}=0.01)$. Jewish religion was overrepresented among HBOS subjects (58\%) compared to HNPCC $(6 \%)$ and FAP $(4 \%, P=0.001)$. Significantly more HBOS subjects had a college education or higher $(83 \%)$ versus HNPCC and FAP ( 51 and 39\%, P = 0.001). Of patients in the HBOS cohort $43 \%$ had breast cancer, while $51 \%$ (HNPCC) and 73\% (FAP) of subjects in the colon cohort had either colorectal cancer or phenotypic manifestations of the colorectal syndrome $(\mathrm{P}=0.04)$. Most of the individuals in the three groups were Caucasian. No statistically significant differences among the three syndromes were found regarding relationship status or having children. Most of the individuals expected a positive genetic test result, regardless of the hereditary cancer syndrome $(74,83$ and $74 \%$ in HNPCC, FAP, and HBOS, respectively, $\mathrm{P}=0.68)$. No statistically significant difference was found in cancer risk perception among individuals at risk for these three syndromes, with $61-78 \%$ considering themselves at high or very high risk of developing cancer $(\mathrm{P}=0.36)$.

\section{Motivations for undergoing genetic testing}

Compared to subjects at risk for HBOS and after controlling for potential confounders, such as disease status, gender, age, and having children, individuals at risk for HNPCC and FAP both independently perceived genetic testing as a tool for cancer prevention and medical management of their syndrome $(\mathrm{P}<0.05)$ (table $3 \mathrm{a})$. Independently of the hereditary cancer syndrome, individuals with an unaffected phenotype also perceived genetic testing as a tool for cancer prevention and medical care of their syndrome $(\mathrm{P}=0.03)$.

Individuals at risk for HNPCC or FAP were more likely than individuals from the breast cohort to report that genetic testing would influence their future and their children's lives ( $\mathrm{P}=0.005$ and $\mathrm{P}=0.02$, respectively) (table $3 \mathrm{~b}$ ).

When asked about their partner's influence on their decision to undergo genetic testing, no statistically significant differences were found among individuals at risk for HNPCC, FAP, and HBOS. However, female subjects were less likely to say their decision was motivated by a partner's wish to know than male subjects $(\mathrm{P}=0.05)$ (table $3 \mathrm{c}$ ).

\section{Concerns about genetic testing}

Individuals from all three hereditary cancer syndromes expressed little concern about their perceived ability to cope with the results (maximum score $=30$, mean scores: HNPCC $=$ 12.45, $\mathrm{FAP}=11.69, \mathrm{HBOS}=12.53, \mathrm{P}=0.65)$ and no other predictors were significantly associated with differences in perceived ability to cope with the results (table 4a).

No statistically significant differences were found among the three hereditary cancer syndromes regarding fear of discrimination (maximum score $=30$, mean scores: HNPCC $=15.27, \quad$ FAP $=15.07, \quad$ HBOS $=14.08, \quad P=0.35)$. However, in the multivariable analysis, unaffected individuals and those with a high perception of developing cancer reported more fear of discrimination $(\mathrm{P}=0.03$ and $\mathrm{P}=0.01$, respectively) (table $4 \mathrm{~b}$ ).

Table 3b Univariate and multivariable analysis of motivations for undergoing genetic testing among HNPCC, FAP, and HBOS syndromes: future planning subscale

\begin{tabular}{|c|c|c|c|}
\hline Future planning subscale & $n$ & FP score, mean (SD) & $P$ value \\
\hline \multicolumn{4}{|l|}{ Cohort } \\
\hline HNPCC & 37 & $10.64(2.09)$ & \\
\hline FAP & 26 & $10.61(3.63)$ & \\
\hline HBOS & 67 & $8.74(2.35)$ & $0.001^{*}$ \\
\hline \multicolumn{4}{|l|}{ Age } \\
\hline$<40$ years & 52 & 9.75 & \\
\hline$>40$ years & 76 & 9.57 & 0.73 \\
\hline \multicolumn{4}{|l|}{ Gender } \\
\hline Female & 105 & $9.51(2.68)$ & \\
\hline Male & 24 & $10.16(2.95)$ & 0.29 \\
\hline \multicolumn{4}{|l|}{ Disease status } \\
\hline Affected & 67 & $9.56(3.01)$ & \\
\hline Unaffected & 63 & $9.76(2.43)$ & 0.68 \\
\hline \multicolumn{4}{|l|}{ Education } \\
\hline$>$ College & 84 & $9.46(2.68)$ & \\
\hline$<$ College & 45 & $9.95(2.82)$ & 0.33 \\
\hline \multicolumn{4}{|l|}{ Income } \\
\hline$<\$ 75000$ & 52 & $9.65(2.96)$ & \\
\hline$>\$ 75000$ & 70 & $9.61(2.60)$ & 0.93 \\
\hline \multicolumn{4}{|l|}{ Partner } \\
\hline No & 38 & $9.44(2.79)$ & \\
\hline Yes & 91 & $9.71(2.72)$ & 0.61 \\
\hline \multicolumn{4}{|l|}{ Individuals with children } \\
\hline No & 31 & $9.22(2.87)$ & \\
\hline Yes & 98 & $9.76(2.69)$ & 0.34 \\
\hline \multicolumn{4}{|l|}{ Risk perception of cancer } \\
\hline High, very high & 89 & $9.79(2.64)$ & \\
\hline Average, low, very low & 35 & $9.40(2.91)$ & 0.46 \\
\hline \multicolumn{4}{|l|}{ Perception of test results } \\
\hline Have an altered gene & 84 & $9.64(2.76)$ & \\
\hline Do not have an altered gene & 27 & $10.40(2.76)$ & 0.21 \\
\hline \multicolumn{2}{|l|}{ Multiple linear regression analysis } & Regression coefficient & $\mathrm{p}$ value \\
\hline \multicolumn{2}{|l|}{ Intercept } & 9.62 & \\
\hline \multicolumn{2}{|l|}{ HNPCC $\dagger$} & 1.66 & 0.005 \\
\hline \multicolumn{2}{|l|}{ FAPt } & 1.55 & 0.02 \\
\hline \multicolumn{2}{|l|}{ Perception of having an altered cancer gene } & -0.84 & 0.15 \\
\hline
\end{tabular}


Table 3c Univariate and multivariable analysis of motivations for undergoing genetic testing among HNPCC, FAP, and HBOS syndromes: partner influence subscale

\begin{tabular}{|c|c|c|c|}
\hline $\begin{array}{l}\text { Partner influence subscale } \\
\text { (only for individuals who have a partner) }\end{array}$ & $n$ & Partner score, mean (SD) & $P$ value \\
\hline \multicolumn{4}{|l|}{ Cohort } \\
\hline HNPCC & 26 & $16.42(2.13)$ & \\
\hline FAP & 17 & 16.29 (4.99) & \\
\hline HBOS & 48 & $15.16(3.15)$ & 0.23 \\
\hline \multicolumn{4}{|l|}{ Age } \\
\hline$<40$ years & 29 & $16.65(2.40)$ & \\
\hline$>40$ years & 61 & $15.29(3.68)$ & 0.07 \\
\hline \multicolumn{4}{|l|}{ Gender } \\
\hline Female & 77 & $15.40(3.48)$ & \\
\hline Male & 14 & $17.57(1.74)$ & 0.02 \\
\hline \multicolumn{4}{|l|}{ Disease status } \\
\hline Affected & 47 & $16.34(3.45)$ & \\
\hline Unaffected & 44 & $15.09(3.16)$ & 0.07 \\
\hline \multicolumn{4}{|l|}{ Education } \\
\hline$>$ College & 63 & 15.63 (3.09) & \\
\hline$<$ College & 28 & $15.96(3.93)$ & 0.66 \\
\hline \multicolumn{4}{|l|}{ Income } \\
\hline$<\$ 75000$ & 23 & $15.95(4.13)$ & \\
\hline$>\$ 75000$ & 64 & $15.70(3.15)$ & 0.76 \\
\hline \multicolumn{4}{|l|}{ Individuals with children } \\
\hline No & 7 & $15.14(7.01)$ & \\
\hline Yes & 84 & $15.78(2.94)$ & 0.81 \\
\hline \multicolumn{4}{|l|}{ Risk perception of cancer } \\
\hline High, very high & 61 & $16.69(2.78)$ & \\
\hline Average, low, very low & 26 & $15.40(3.59)$ & 0.10 \\
\hline \multicolumn{4}{|l|}{ Perception of test results } \\
\hline Have an altered gene & 58 & $15.70(3.84)$ & \\
\hline Do not have an altered gene & 19 & $16.31(2.45)$ & 0.52 \\
\hline \multicolumn{2}{|l|}{ Multiple linear regression analysis } & Regression coefficient & $P$ value \\
\hline \multicolumn{2}{|l|}{ Intercept } & 11.64 & \\
\hline \multicolumn{2}{|l|}{ HNPCC $†$} & 0.89 & 0.27 \\
\hline \multicolumn{2}{|l|}{ FAP $†$} & 0.17 & 0.86 \\
\hline \multicolumn{2}{|l|}{ Gender (female) } & -1.89 & 0.05 \\
\hline \multicolumn{2}{|l|}{ Age (>40 years) } & -1.37 & 0.07 \\
\hline \multicolumn{2}{|l|}{ Disease status (unaffected) } & -1.07 & 0.13 \\
\hline \multicolumn{2}{|l|}{ Risk perception of cancer (high, very high) } & -0.53 & 0.37 \\
\hline
\end{tabular}

\section{DISCUSSION}

The results of the present study suggest that individuals at risk for HNPCC and FAP were more likely than individuals at risk for HBOS to undergo genetic testing for the purpose of making plans for cancer prevention and making decisions about their medical care. Also, individuals at risk for hereditary colorectal cancer syndromes were more likely than subjects at risk for HBOS to perceive that genetic testing would influence their life and their children's lives. Interestingly, subjects from all three hereditary cancer syndromes expressed relatively little concern regarding their perceived ability to cope with the genetic test results. No differences were found regarding fear of discrimination among the three syndromes.

Current evidence in the literature supports the benefit of surveillance in individuals at risk for HNPCC. ${ }^{14}{ }^{15}$ Mutation carriers of HNPCC-associated genes have more stringent cancer screening recommendations than the population at average risk of colon cancer. It is recommended that mutation carriers and individuals at risk begin screening at age 25 with annual colonoscopy, and that women also undergo annual endometrial screening with pelvic ultrasound and endometrial biopsy starting at age 30-35. ${ }^{16}$ Considering these recommendations, members of HNPCC families may decide to undergo genetic testing to determine whether they are at risk and require these procedures. In fact, there is some evidence in the literature that suggests one of the main motivations for undergoing genetic testing in these individuals is guiding cancer screening for HNPCC. ${ }^{11}{ }^{12}$

Interest in being tested for prevention and medical management among individuals at risk for FAP is also easily justifiable. Unaffected carrier individuals would be recommended to follow a strict protocol of surveillance starting in their adolescence if tested positive, which could be avoided in those individuals at risk who tested negative. ${ }^{17}{ }^{18}$ Moreover, surgical prevention of cancer in FAP has already been established and incorporated as part of standard practice in the management of these patients.

In contrast, mammography is an early detection strategy for breast cancer rather than a preventive measure. Although it reduces mortality for breast cancer in the general population over 50 years of age, ${ }^{19}$ it has not proven to be very effective in early detection of cancer when performed in a high-risk population. ${ }^{20}$ In contrast, colonoscopy has been reported to decrease colorectal cancer incidence in HNPCC by $62 \%$ and overall mortality by $65 \%$ when performed in mutation carriers and individuals at risk. ${ }^{14}$ Moreover, in models of decision analysis, longer life expectancy has been estimated in individuals at risk for HNPCC who undergo surveillance with colonoscopy ${ }^{21}{ }^{22}$ compared to estimated life expectancy among individuals at risk for HBOS who undergo surveillance with mammography. ${ }^{23}$ Nevertheless, prophylactic surgeries, such as bilateral mastectomy or oophorectomy, have been shown to be more effective methods to reduce the 
Table 4a Univariate and multivariable analysis of concerns about genetic testing among HNPCC, FAP, and HBOS syndromes: ability to cope subscale

\begin{tabular}{|c|c|c|c|}
\hline Ability to cope subscale & $n$ & ATC score, mean (SD) & $P$ value \\
\hline \multicolumn{4}{|l|}{ Cohort } \\
\hline HNPCC & 37 & $12.45(3.88)$ & \\
\hline FAP & 26 & $11.69(4.11)$ & \\
\hline HBOS & 67 & $12.53(4.20)$ & $0.65^{*}$ \\
\hline \multicolumn{4}{|l|}{ Age } \\
\hline$<40$ years & 52 & $12.61(4.20)$ & \\
\hline$>40$ years & 76 & $12.22(4.04)$ & 0.59 \\
\hline \multicolumn{4}{|l|}{ Gender } \\
\hline Female & 105 & $12.55(4.22)$ & \\
\hline Male & 24 & 11.58 (3.34) & 0.29 \\
\hline \multicolumn{4}{|l|}{ Disease status } \\
\hline Affected & 67 & $11.74(4.05)$ & \\
\hline Unaffected & 63 & $12.98(4.04)$ & 0.08 \\
\hline \multicolumn{4}{|l|}{ Education } \\
\hline$>$ College & 84 & $12.57(4.02)$ & \\
\hline$<$ College & 45 & $12.00(4.20)$ & 0.45 \\
\hline \multicolumn{4}{|l|}{ Income } \\
\hline$<\$ 75000$ & 52 & $12.30(4.54)$ & \\
\hline$>\$ 75000$ & 70 & $12.31(3.79)$ & 0.99 \\
\hline \multicolumn{4}{|l|}{ Partner } \\
\hline No & 38 & $12.42(4.16)$ & \\
\hline Yes & 91 & $12.35(4.07)$ & 0.93 \\
\hline \multicolumn{4}{|l|}{ Individuals with children } \\
\hline No & 31 & $12.77(4.12)$ & \\
\hline Yes & 98 & $12.24(4.08)$ & 0.53 \\
\hline \multicolumn{4}{|l|}{ Risk perception of cancer } \\
\hline High, very high & 89 & $11.97(4.59)$ & \\
\hline Average, low, very low & 35 & $12.53(3.97)$ & 0.49 \\
\hline \multicolumn{4}{|l|}{ Perception of test results } \\
\hline I have an altered gene & 84 & $11.83(3.83)$ & \\
\hline I do not have an altered gene & 27 & $12.88(4.08)$ & 0.22 \\
\hline \multicolumn{2}{|l|}{ Multiple linear regression analysis } & Regression coefficient & $P$ value \\
\hline & 12.75 & \\
\hline HNPCC $\dagger$ & & 0.01 & 0.98 \\
\hline \multicolumn{2}{|l|}{ FAPt } & -0.97 & 0.33 \\
\hline \multicolumn{2}{|l|}{ Disease status (unaffected) } & 0.15 & 0.85 \\
\hline \multicolumn{2}{|l|}{ Perception of having an altered cancer gene } & -0.90 & 0.34 \\
\hline
\end{tabular}

risk of breast and ovarian cancer compared to surveillance protocols in BRCAl and BRCA2 mutation carriers. ${ }^{23-30}$ These types of surgeries, however, may be perceived as mutilating or aggressive approaches by many women ${ }^{31}$ and beneficial results from observational studies had not been reported by the time most of the individuals at risk for HBOS enrolled in our study. Since prophylactic oophorectomy started to be recommended, it has been preferred over prophylactic mastectomy by most women, ${ }^{32}{ }^{33}$ while surveillance strategies are more acceptable for breast cancer.

These differences in efficacy of surveillance methods among HNPCC, FAP, and HBOS, in addition to the perceived mutilation and low acceptance of prophylactic measures in HBOS could explain why individuals at risk for hereditary breast cancer placed slightly lower value on cancer prevention and medical management as motivations for genetic testing compared with individuals at risk for hereditary colon cancer.

Individuals from all three hereditary cancer syndromes reported little concern regarding their perceived ability to cope emotionally with the genetic test results. There are data in the literature that support these results. In two recent studies conducted among individuals who agreed to undergo genetic testing for HNPCC, concerns about how to handle the results emotionally were assessed as important by only about $10 \%$ of the probands. ${ }^{12}{ }^{13}$ Another study with individuals at risk for hereditary colon cancer concluded that intention to learn test results was correlated with the belief that one has the ability to cope with the results. ${ }^{34}$ It has also been reported that depression rate seems to decrease in those subjects who undergo genetic testing for BRCAl and BRCA2 and are found to be non-carriers, and it remains the same in carriers ${ }^{35}$; however, it increases in those who decline genetic testing. All these data suggest that individuals who accept genetic testing for hereditary cancer syndromes are a selected group with a good ability to cope emotionally with the results. It is expected that these results may not hold true if a broader population of individuals at risk for hereditary cancer syndromes including decliners of genetic testing was studied.

Some differences among subjects were found to be independent of the hereditary cancer group. Unaffected individuals expressed more interest in undergoing genetic testing for the purpose of gaining knowledge about prevention and medical management of their syndrome compared to affected subjects. These findings may be logical since prevention strategies for these syndromes yield greater life expectancy in healthy individuals compared with those who have already developed cancer. ${ }^{22}{ }^{23}{ }^{36}$ Unaffected subjects and those who had a perception of high risk of developing cancer expressed more fear of potential discrimination compared to affected patients and subjects with a lower risk perception of cancer. Fear of discrimination is commonly reported as a concern among subjects who undergo genetic testing. It has been expressed by individuals who are tested for BRCAl and BRCA2, ${ }^{37}$ among women with an Ashkenazi Jewish ancestry and a high education level, ${ }^{38}$ and by subjects who are tested for HNPCC..$^{11}{ }^{12}$ The concern for life insurance has been 
Table 4b Univariate and multivariable analysis of concerns about genetic testing among HNPCC, FAP, and HBOS syndromes: fear of discrimination subscale

\begin{tabular}{|c|c|c|c|}
\hline Fear of discrimination subscale & $n$ & FOD score, mean (SD) & P value \\
\hline \multicolumn{4}{|l|}{ Cohort } \\
\hline HNPCC & 37 & $15.27(4.28)$ & \\
\hline FAP & 26 & $15.07(5.12)$ & \\
\hline HBOS & 67 & $14.08(4.12)$ & $0.35^{*}$ \\
\hline \multicolumn{4}{|l|}{ Age } \\
\hline$<40$ years & 52 & $15.48(4.75)$ & \\
\hline$>40$ years & 76 & $14.01(4.07)$ & 0.06 \\
\hline \multicolumn{4}{|l|}{ Gender } \\
\hline Female & 105 & $14.30(4.40)$ & \\
\hline Male & 24 & $15.87(4.17)$ & 0.11 \\
\hline \multicolumn{4}{|l|}{ Disease status } \\
\hline Affected & 67 & $13.92(4.34)$ & \\
\hline Unaffected & 63 & $15.36(4.33)$ & 0.06 \\
\hline \multicolumn{4}{|l|}{ Education } \\
\hline$>$ College & 84 & $14.92(4.01)$ & \\
\hline$<$ College & 45 & $13.97(5.01)$ & 0.24 \\
\hline \multicolumn{4}{|l|}{ Income } \\
\hline$<\$ 75000$ & 52 & $14.15(5.00)$ & \\
\hline$>\$ 75000$ & 70 & $14.84(3.93)$ & 0.39 \\
\hline \multicolumn{4}{|l|}{ Partner } \\
\hline No & 38 & $14.26(5.23)$ & \\
\hline Yes & 91 & $14.73(4.01)$ & 0.57 \\
\hline \multicolumn{4}{|l|}{ Having children } \\
\hline No & 31 & $14.16(5.13)$ & \\
\hline Yes & 98 & $14.73(4.14)$ & 0.52 \\
\hline \multicolumn{4}{|l|}{ Risk perception of cancer } \\
\hline High, very high & 89 & $15.11(4.52)$ & \\
\hline Average, low, very low & 35 & $13.51(4.08)$ & 0.07 \\
\hline \multicolumn{4}{|l|}{ Perception of test results } \\
\hline Have an altered gene & 84 & $14.64(4.46)$ & \\
\hline Do not have an altered gene & 27 & $14.33(3.80)$ & 0.74 \\
\hline \multicolumn{2}{|l|}{ Multiple linear regression analysis } & Regression coefficient & P value \\
\hline Intercept & & 10.82 & \\
\hline HNPCC $\dagger$ & & 1.57 & 0.10 \\
\hline FAPt & & 2.08 & 0.07 \\
\hline Age ( $>40$ years) & & -0.81 & 0.32 \\
\hline Gender (female) & & -1.36 & 0.18 \\
\hline Education (>college) & & 1.67 & 0.06 \\
\hline Disease status (unaffected) & & 1.78 & 0.03 \\
\hline Risk perception of cancer (high, very high) & & 2.18 & 0.01 \\
\hline
\end{tabular}

previously reported as a reason to decline genetic testing ${ }^{5}$ and it highlights the importance of developing policies to support this new medical technology. It might be that affected subjects express less fear of discrimination related to genetic testing because most of them have already been diagnosed with cancer.

Despite males being a small group in this study, they were more likely than females to report that the decision to undergo genetic testing was influenced by their partner's wishes. This may correlate with the higher uptake of genetic testing reported previously in women compared with men among first-degree relatives of patients with colon cancer, ${ }^{5}$ other HNPCC cohorts $^{13}{ }^{39}$, and in Huntington's disease. ${ }^{40}$

Our study had several limitations. Our cohort reflects motivations and concerns regarding genetic testing of individuals who were self-motivated to undergo genetic testing. Since the study was conducted only among test acceptors, we suspect that concerns regarding genetic testing may have been underestimated. It would be interesting to analyse the differences in motivations and concerns regarding genetic testing between acceptors and decliners of genetic testing in these hereditary cancer syndrome populations. Moreover, the study was conducted in only one centre and most of the subjects were Caucasian.

In conclusion, our study demonstrates that many individuals at risk for hereditary cancer syndromes consider genetic testing to be part of their medical management. The comparison of motivations and concerns about genetic testing between high-risk breast and colon cohorts provides us with valuable information about differences and similarities among HNPCC, FAP, and HBOS patients as well as the differences that are independent of the hereditary cancer syndrome. Whether emerging data about the effectiveness of prophylactic surgery leads to changes in perceptions about impact of genetic testing in HBOS patients should be addressed in future studies.

\section{ACKNOWLEDGEMENTS}

Judith Balmaña is a recipient of a grant from "La Caixa", Barcelona, Spain. Dr. Syngal's research is supported by NIH grant K07CA08453 for cancer screening compliance in hereditary colon cancer.

We thank Laoti Bussone MPH for helping in the collection of data and the Measurement Core of the Dana-Farber Harvard Cancer Center, especially Laura Richman for her assistance in data analysis.

\section{Authors' affiliations}

J Balmaña, E M Stoffel, K M Emmons, J E Garber, S Syngal, Population Sciences, Dana-Farber Cancer Institute, Gastroenterology Division, Brigham and Women's Hospital, Boston, MA, USA

Correspondence to: Dr. Sapna Syngal, Medical Oncology, DanaFarber Cancer Institute, Smith 209, 44 Binney Street, Boston, MA 02115, USA; ssyngal@partners.org

Received 15 July 2003 


\section{APPENDIX A. MACGNET INSTRUMENT (5-POINT LIKERT-SCALE FROM STRONGLY DISAGREE TO STRONGLY AGREE)}

\section{1) MEDICAL CARE AND PREVENTION}

- Learning my results will allow me to plan better for the future.

- I want to learn my results, so I can get appropriate medical care.

- If I have an altered cancer gene, I want to know

- Learning my results will help me to prevent cancer

- I want to know what my chances are of getting cancer.

- I want to learn my results, so I will know my children's chances of getting cancer.

- Learning my results will help my doctor and me to make a plan for monitoring for signs of cancer.

- Learning my results will help my doctor and me make decisions about treatment.

- Learning my results will help me live longer.

- Knowing if I have the altered cancer gene will not help me to prevent cancer.

- If I do not have an altered cancer susceptibility gene, I want to know.

2) PARTNER'S WISH TO KNOW

- It is important for my partner that I am tested.

- My partner does not want to know if I have an altered cancer susceptibility gene.

- My partner will be angry if I go ahead with testing.

- Being tested is the responsible thing to do.

\section{3) FUTURE PLANNING}

- Knowing that I DO have an altered cancer susceptibility gene will help me to live my life to the fullest.

- Learning my results will help my children make decisions about marriage and family.

- Knowing that I DO NOT have an altered cancer susceptibility gene will help me to live my life to the fullest.

\section{4) ABILITY TO COPE WITH THE RESULTS}

- I do not know how I would cope with knowing that I have an altered cancer susceptibility gene.

- Learning my results will be upsetting to me.

- Knowing my results will change how I feel about myself.

- I will be fine emotionally regardless of what my results are.

- It would be overwhelming to know that I have an extremely high chance of developing cancer.

- It seems wrong to have this type of testing. Time will tell if I have an altered gene.

\section{5) FEAR OF DISCRIMINATION}

- I am worried about losing my health insurance if I have an altered cancer susceptibility gene.

- If I have an altered cancer susceptibility gene I will not be able to obtain or maintain life insurance.
- Learning that I do not have an altered cancer susceptibility gene will protect my family's health insurance.

- Having an altered cancer susceptibility gene will make it difficult for my family members to get or keep health insurance.

- I may be discriminated against if I learn my results.

- I am worried about the consequences if my employer finds out my results.

\section{REFERENCES}

1 Croyle RT, Lerman C. Interest in genetic testing for colon cancer susceptibility: cognitive and emotional correlates. Prev Med 1993;22(2):284-92.

2 Lerman C, Daly M, Masny A, Balshem A. Attitudes about genetic testing for breast-ovarian cancer susceptibility. J Clin Oncol 1994; 12(4):843-50.

3 Lerman C, Seay J, Balshem A, Audrain J. Interest in genetic testing among first-degree relatives of breast cancer patients. Am J Med Genet 1995; 57(3):385-92.

4 Glanz K, Grove J, Lerman C, Gotay C, Le Marchand L. Correlates of intentions to obtain genetic counseling and colorectal cancer gene testing among at-risk relatives from three ethnic groups. Cancer Epidemiol Biomarkers Prev 1999:8(4 Pt 2):329-36.

5 Lerman C, Marshall J, Audrain J, Gomez-Caminero A. Genetic testing for colon cancer susceptibility: Anticipated reactions of patients and challenges to providers. Int J Cancer 1996;69(1):58-61.

6 Petersen GM, Larkin E, Codori AM, Wang CY, Booker SV, Bacon J Giardiello FM, Boyd PA. Attitudes toward colon cancer gene testing: survey of relatives of colon cancer patients. Cancer Epidemiol Biomarkers Prev 1999;8(4 Pt 2):337-44.

7 Lerman C, Narod S, Schulman K, Hughes C, Gomez-Caminero A, Bonney G, Gold K, Trock B, Main D, Lynch J, Fulmore C, Snyder C, Lemon SJ, Conway T, Tonin P, Lenoir G, Lynch H. BRCAl testing in families with hereditary breastovarian cancer. A prospective study of patient decision making and outcomes. JAMA 1996;275(24):1885-92.

8 Lerman C, Hughes C, Trock BJ, Myers RE, Main D, Bonney A, Abbaszadegan MR, Harty AE, Franklin BA, Lynch JF, Lynch HT. Genetic testing in families with hereditary nonpolyposis colon cancer. JAMA 1999;281(17): 1618-22.

9 Foster C, Evans DG, Eeles R, Eccles D, Ashley S, Brooks L, Davidson R, Mackay J, Morrison PJ, Watson M. Predictive testing for BRCA1/2: attributes, risk perception and management in a multi-centre clinical cohort. $\mathrm{Br} J$ Cancer 2002;86(8): 1209-16.

10 Brandt R, Hartmann E, Ali Z, Tucci R, Gilman P. Motivations and concerns of women considering genetic testing for breast cancer: a comparison between affected and at-risk probands. Genet Test 2002;6(3):203-5.

11 Esplen MJ, Madlensky L, Butler K, McKinnon W, Bapat B, Wong J, Aronson M, Gallinger S. Motivations and psychosocial impact of genetic testing for HNPCC. Am J Med Genet 2001;103(1):9-15.

12 Hadley DW, Jenkins J, Dimond E, Nakahara K, Grogan L, Liewehr DJ, Steinberg SM, Kirsch I. Genetic counseling and testing in families with hereditary nonpolyposis colorectal cancer. Arch Intern Med 2003; 163(5):573-82.

13 Aktan-Collan K, Mecklin JP, Jarvinen H, Nystrom-Lahti M, Peltomaki P, Soderling I, Uutela A, de la Chapelle A, Kaariainen H. Predictive genetic testing for hereditary non-polyposis colorectal cancer: uptake and long-term satisfaction. Int J Cancer 2000;89(1):44-50.

14 Jarvinen HJ, Aarnio M, Mustonen H, Aktan-Collan K, Aaltonen LA Peltomaki P, De La Chapelle A, Mecklin JP. Controlled 15-year trial on screening for colorectal cancer in families with hereditary nonpolyposis colorectal cancer. Gastroenterology 2000;1 18(5):829-34.

15 Renkonen-Sinisalo L, Aarnio M, Mecklin JP, Jarvinen HJ. Surveillance improves survival of colorectal cancer in patients with hereditary nonpolyposis colorectal cancer. Cancer Detect Prev 2000;24(2):137-42.

16 Burke W, Petersen G, Lynch P, Botkin J, Daly M, Garber J, Kahn MJ, McTieman A, Offit K, Thomson E, Varricchio C. Recommendations for followup care of individuals with an inherited predisposition to cancer. I. Hereditary nonpolyposis colon cancer. Cancer Genetics Studies Consortium. JAMA 1997;277(11):915-9.

17 King JE, Dozois RR, Lindor NM, Ahlquist DA. Care of patients and their families with familial adenomatous polyposis. Mayo Clin Proc 2000;75(1):57-67

18 Giardiello FM, Brensinger JD, Petersen GM. AGA technical review on hereditary colorectal cancer and genetic testing. Gastroenterology 2001;121(1):198-213.

19 Kerlikowske K, Grady D, Rubin SM, Sandrock C, Ernster VL. Efficacy of screening mammography. A meta-analysis. JAMA 1995;273(2): 149-54.

20 Brekelmans CT, Seynaeve C, Bartels CC, Tilanus-Linthorst MM, MeijersHeijboer EJ, Crepin CM, van Geel AA, Menke M, Verhoog LC, van den Ouweland A, Obdeijn IM, Klijn JG; Rotterdam Committee for Medical and Genetic Counseling. Effectiveness of breast cancer surveillance in BRCA1/2 gene mutation carriers and women with high familial risk. J Clin Oncol 2001; 19(4):924-30. 
21 Vasen HF, van Ballegooijen M, Buskens $E$, Kleibeuker JK, Taal BG Griffioen G, Nagengast FM, Menko FH, Meera Khan P. A cost-effectiveness analysis of colorectal screening of hereditary nonpolyposis colorectal carcinoma gene carriers. Cancer 1998;82(9):1632-7.

22 Syngal S, Weeks JC, Schrag D, Garber JE, Kuntz KM. Benefits of colonoscopic surveillance and prophylactic colectomy in patients with hereditary nonpolyposis colorectal cancer mutations. Ann Intern Med 1998; 129(10):787-96.

23 Grann VR, Jacobson JS, Thomason D, Hershman D, Heitjan DF, Neugut Al. Effect of prevention strategies on survival and quality-adjusted survival of women with BRCA1/2 mutations: an updated decision analysis. J Clin Oncol 2002;20(10):2520-9.

24 Schrag D, Kuntz KM, Garber JE, Weeks JC. Decision analysis-effects of prophylactic mastectomy and oophorectomy on life expectancy among women with BRCA1 or BRCA2 mutations. N Engl J Med 1997;336(20): 1465-71.

25 Hartmann LC, Schaid DJ, Woods JE, Crotty TP, Myers JL, Arnold PG, Petty PM, Sellers TA, Johnson JL, McDonnell SK, Frost MH, Jenkins RB. Efficacy of bilateral prophylactic mastectomy in women with a family history of breast cancer. N Engl J Med 1999;340(2):77-84.

26 van Roosmalen MS, Verhoef LC, Stalmeier PF, Hoogerbrugge N, van Daal WA. Decision analysis of prophylactic surgery or screening for BRCA1 mutation carriers: a more prominent role for oophorectomy. J Clin Oncol 2002;20(8):2092-100.

27 Rebbeck TR, Levin AM, Eisen A, Snyder C, Watson P, Cannon-Albright L, Isaacs C, Olopade O, Garber JE, Godwin AK, Daly MB, Narod SA, Neuhausen SL, Lynch HT, Weber BL. Breast cancer risk after bilatera prophylactic oophorectomy in BRCA1 mutation carriers. J Natl Cancer Inst 1999;91(17): 1475-9.

28 Meijers-Heijboer H, van Geel B, van Putten WL, Henzen-Logmans SC, Seynaeve C, Menke-Pluymers MB, Bartels CC, Verhoog LC, van den Ouweland AM, Niermeijer MF, Brekelmans CT, Klijn JG. Breast cancer after prophylactic bilateral mastectomy in women with a BRCA1 or BRCA2 mutation. N Engl J Med 2001;345(3): 159-64.

29 Rebbeck TR, Lynch HT, Neuhausen SL, Narod SA, Van't Veer L, Garber JE, Evans G, Isaacs C, Daly MB, Matloff E, Olopade OI, Weber BL. Prophylactic oophorectomy in carriers of BRCA1 or BRCA2 mutations. N Engl J Med 2002;346(21):1616-22.
30 Kauff ND, Satagopan JM, Robson ME, Scheuer L, Hensley M, Hudis CA, Ellis NA, Boyd J, Borgen PI, Barakat RR, Norton I, Castiel M, Nafa K, Offit K. Risk-reducing salpingo-oophorectomy in women with a BRCA1 or BRCA2 mutation. N Engl J Med 2002;346(21):1609-15.

31 Hallowell N. 'You don't want to lose your ovaries because you think "I might become a man"'. Women's perceptions of prophylactic surgery as a cancer risk management option. Psychooncology 1998;7(3):263-75.

32 Eisen A, Rebbeck TR, Wood WC, Weber BL. Prophylactic surgery in women with a hereditary predisposition to breast and ovarian cancer. J Clin Oncol 2000; 18(9): 1980-95.

33 Meijers-Heijboer EJ, Verhoog LC, Brekelmans CT, Seynaeve C, TilanusLinthorst $M M$, Wagner A, Dukel L, Devllee $P$, van den Ouwaland $A M$, van Geel AN, Klijn JG. Presymptomatic DNA testing and prophylactic surgery in families with a BRCA1 or BRCA2 mutation. Lancet 2000;355(9220):2015-20.

34 Vernon SW, Gritz ER, Peterson SK, Perz CA, Marani S, Amos Cl, Baile WF. Intention to learn results of genetic testing for hereditary colon cancer. Cancer Epidemiol Biomarkers Prev 1999:8(4 Pt 2):353-60.

35 Lerman C, Hughes C, Lemon SJ, Main D, Snyder C, Durham C, Narod S, Lynch HT. What you don't know can hurt you: adverse psychologic effects in members of BRCA1-linked and BRCA2-linked families who decline genetic testing. J Clin Oncol 1998;16(5):1650-4.

36 Schrag D, Kuntz KM, Garber JE, Weeks JC. Life expectancy gains from cancer prevention strategies for women with breast cancer and BRCA1 or BRCA2 mutations. JAMA 2000;283(5):617-24

37 Peterson EA, Milliron KJ, Lewis KE, Goold SD, Merajver SD. Health insurance and discrimination concerns and $\mathrm{BRCAl} / 2$ testing in a clinic population. Cancer Epidemiol Biomarkers Prev 2002;11(1):79-87.

38 Lehmann LS, Weeks JC, Klar N, Garber JE. A population-based study of Ashkenazi Jewish women's attitudes toward genetic discrimination and BRCA1/2 testing. Genet Med 2002;4(5):346-52.

39 Wagner A, Tops $C$, Wiinen J, Zwinderman K, van Der Meer C, Kets M, Niermeijer MF, Klijn JG, Tibben A, Vasen HF, Meijers-Heijboer H. Genetic testing in hereditary non-polyposis colorectal cancer families with a MSH2, MLH1, or MSH6 mutation. J Med Genet 2002;39:833-837.

40 Maat-Kievit A, Vegter-Van der Vlis M, Zoeteweii M, Losekoot M, van Haeringen A, Roos R. Paradox of a better test for Huntington's disease. J Neurol Neurosurg Psychiatry 2000;69:579-583. 